\title{
Az Arvisura és a FÉRAN, a Beavatottak Névadó Naptára - alkalmazott névtani megközelítésben
}

1. A tanulmány témája, célja és módszerei. Tanulmányomban Paál Zoltán Arvisura - Igazszólás címü, a magyarság számára egy alternatív mitológiát, illetve történelmet megrajzoló művét, illetve annak VIII. nagy egységét, a FÉRAN névadó naptárt vizsgálom. A teljes Arvisura mára már antikváriumokból is csak nehezen és költségesen szerezhető be, és az érintett szubkultúrába tartozókon kívül csak kevesen hallottak róla. Ezzel szemben a FÉRAN naptár ismertsége és népszerüsége régen túlnőtt a forrásművön: napjainkban leggyakrabban önálló formában jelenik meg, föként az interneten. Több alternatív nép- és nyelveredetet hirdető portál vagy blog akár teljes oldalakat tesz közzé a naptár neveiből. Ha olyan nevekre keresünk rá, amelyek nem Paálnál jelentek meg először, sok esetben az első találatok között vagy egyedüli találatként a FÉRAN naptárat találjuk. Ráadásul számos nevet, amelyek Paál alkotásai, a Magyar Keresztnevek Tára (MKT.) és a hasonló internetes utónévkeresők az anyakönyvezhetö keresztnevekkel együtt tüntetik fel (némelyikük minden megkülönböztetés nélkül; vö. FARKAS 2019). Ezeken felül a közösségi médiában több olyan nyílt és zárt csoportot találni, amelyeknek a középpontjában a FẺRAN és nevei állnak. Ezek általában pár hónapos fennállás után eltünnek, hogy rövid időn belül új, hasonló rendeltetésủ csoportok jelenhessenek meg. Hasonló körforgásban van a naptár teljes szövege is, amely szintén csak időnként érhetö el az interneten.

Kutatásomnak nem célja a teljes Arvisura részletes áttekintése, ez már a mü terjedelméből (1454 oldal) is következik. Elsődleges célkitüzésem tehát az, hogy a kiemelt VIII. részt, a FÉRANt és annak névállományát a lehetőségek szerinti legtöbb szempontból bemutassam és vizsgáljam. A szempontok közé tartozik a naptárnak a mủ egészében betöltött szerepe is, ezért az Arvisura bizonyos mértékủ bemutatása természetesen megkerülhetetlen. Elsősorban arra a kérdésre keresem a választ, hogy mi indokolhatja az Arvisura körüli szubkultúra kialakulását, illetve hogyan tudott a FÉRAN névadó naptár túllépni ezen a hatókörön, és a mai napig releváns maradni a laikusok nevek iránti érdeklődésének kielégítésében.

A tanulmányban elsőként áttekintem a témakör néhány jellemzőjét az újabb szakirodalom alapján, amely az Arvisuráéhoz hasonló nyelvi ideológiai közösségek univerzális tulajdonságait tárgyalja. Ezután általános bemutatását adom az Arvisura felépítésének, tartalmának és céljának, amennyire a tanulmány keretei ezt megengedik. Majd a FÉRAN részletesebb leírása következik, amely elengedhetetlen előismeretként szolgál az elemzés teljes körü megértéséhez. Ezt követi a tanulmány központi része, a naptár egy kijelölt névállományának névtani szempontú elemzése. Az elemzés szempontjait és módszerét az adott részben részletesen ismertetem. Végül a kapott eredmények összegzése, a következtetések levonása és a lezárás kap helyet.

2. Az Arvisurák és a laikus rokonságelméletek. Az Arvisurák által felvázolt világkép és a FÉRAN által kijelölt névadási hagyományok tökéletesen beleilleszkednek az áltudományos nyelvi ideológiák és laikus nyelvrokonítási kísérletek kiterjedt problémakörébe. 
Ezen ideológiák alapvető közös tulajdonsága, hogy a magyar nyelvet általánosan „megbecsült" és nagy múltú nyelvekkel igyekeznek rokonsági kapcsolatba hozni, illetve minél egyedibb, központibb szereppel felruházni. Ennek a jelenségnek az egyik legszélsőségesebb esetével találkozhatunk az Arvisura-kultuszban, amely a világ minden nevét a magyarból, pontosabban a ,palóc nyelvböl” eredezteti.

Az ilyen témájú mủvek szerzőiről általánosan elmondható, hogy a nyelvészet tudományában képzetlenek, vagy ha folytattak is nyelvészeti tanulmányokat, a nyelvek történeti összehasonlító kutatásához szükséges tudást nem sajátították el. Ez Paál Zoltánra is igaz, hiszen sem tanulmányait, sem szakmáját tekintve nem került szorosabb kapcsolatba a nyelvtudomány területeivel.

Az efféle nézetek egyre népszerübbé válásában az egyik meghatározó oknak a társadalomban elterjedt, a bölcsészettudománnyal szembeni lenéző, szkeptikus magatartás tekinthetö. Ezt a viszonyulást indokolhatja az, hogy a humán tudományok általában könnyebben kerülhetnek politikai befolyás alá. Emellett a reál tudományokkal szemben a bölcsészetnek gyakran közvetett és lassan jelentkező haszna van, míg az orvostudománynak vagy akár a gépészetnek sokkal kézzelfoghatóbbak az eredményei, és nagyobb szerepet töltenek be a mindennapi életben (IMREH 2017).

A történeti okok között kulcsfontosságú egy kialakult séma, a magyar nép úgynevezett áldozati szerepe. A magyar társadalom egyes rétegeiben a mai napig kimagasló szerep jut a dicső múlt hangsúlyozásának, szemben a jelen kevésbé dicső állapotával. Ha az áldozati szerepnek gyakran nincs is aktuális, aktív kiváltó oka, a korábbi negatív történeti események emlékezete fenntartja a sémát, és a dicső magyar múlt képének éltetése mellett a mindenkori ,idegen” beavatkozó erőtől való félelem is negatív velejárója ennek a felfogásnak. (Vö. SÁndor 2011: 415-416.)

Ezt a félelmet tovább erősíti az is, hogy a magyarnak nincs olyan, földrajzi és nyelvi értelemben egyaránt közeli nyelvrokona, mint a germán, szláv stb. nyelveket beszélö népeknek. Ez alapvető oka lehet annak a jelenségnek, hogy számos ilyen ideológia kitüntetett, mitikus szerepkörrel ruházza fel a magyar nyelvet és a magyar népet is. A politikai hátterü nyelvi ideológiák gyakori jellemzője, hogy a nyelvet a nemzettel teljesen azonosítják, és politikai célok eléréséhez használják fel (LANSTYÁK 2011: 22-25).

Okolható még ezen eszmék terjedéséért az összeesküvés-elméletekre való fogékonyság; föként azok említendők itt, amelyek kollektívan a tudományos közösségek ellen irányulnak. Ezek az áltudományos elméletek leegyszerüsített, könnyen felfogható, de nem igazolható magyarázatokat szolgáltatnak a tudományosakkal szemben. (Vö. KREKó 2018: 147-155.) A nehezebben feldolgozható tényeket és az időigényesebb vizsgálódásokat a laikusok gyakran azzal magyarázzák, hogy bizonyos elitista, központi erők vagy idegen háttérhatalmak nem kívánják megosztani a valós tudást a néppel, így lehetetlenítik el az egyébként egyértelmü igazságokat. Ez a mentalitás a magyar társadalomban is megtalálható, egyes részlegeiben jellemzőnek is tekinthető.

IMREH (2017) az ideológiák terjedésének további okát a közoktatás hiányosságaiban látja. Ennek egyik meghatározó tényezője, hogy a diákok felfogásában az iskolában megszerzett tudás és a valódi életben alkalmazható, hasznos tudás távol áll egymástól. Az iskolában elsajátított tudásra gyakran nem valós tényekként tekintenek, és a diákként megszerzett információkat könnyen cserélik fel máshonnan megszerzett tapasztalatokkal vagy a különböző médiumok által terjesztett nézetekkel. Különösen érvényes ez a nyelvünk 
eredetére és történetére vonatkozó tudásra, ugyanis erre a témakörre a közoktatás csekély óraszámot biztosít. Ezenfelül a magyar közoktatás nem segíti a diákok kritikai szemléletének kialakítását, így nem tudnak különbséget tenni a tényekkel alátámasztott tudományos értekezések és az áltudományos írások közt. Nézőpontjukat, véleményüket gyakran teljes mértékben a különböző tekintélyek, valamint a családjuk és közvetlen környezetük politikai beállítottsága és meggyőződései határozzák meg.

Itt érdemes kiemelni, hogy a legtöbb alternatív elmélet nem tesz különbséget nyelv- és néprokonság közt. (Ez a jelenség is megjelenik többek között az Arvisurában.) Előfordul, hogy az iskolai tankönyvek is felcserélhetönek tekintik a két fogalmat, és nem hívják fel arra a figyelmet, hogy a nyelvrokonság a nyelvészet hatáskörébe tartozik, és mára sokkal inkább tudományos tény, mintsem eldöntendő kérdés.

Számos tanulmány és monográfia általánosan foglalkozik az alternatív elméletekkel, újabban pedig már olyan munkák is születtek, amelyek a személy- és helyneveknek ezen elméletekben betöltött szerepét vizsgálják (IMreH 2014, 2015; Zelliger 2017; SLíz 2018, 2020a). Mivel az Arvisura és az IMREH RéKA (2014, 2015) által vizsgált Pilis-kultusz több ponton is érintkezik, a következőkben az Arvisura jellemzőit ezzel összehasonlítva, s a fenti két IMREH-tanulmányra támaszkodva mutatom be.

Mindkét kultuszban alapvető szerepet játszik a magyar nép számára meghatározó, eddig fel nem lelt, a felszín alatt bujkáló ,,valós” történelem. Ezek a történelmi titkok gyakran (korábban) Magyarország területén található vagy Magyarországhoz kapcsolható konkrét földrajzi helyekkel állnak szoros kapcsolatban. Ilyenek a Pilis-kultusz esetében a Pilis és Dobogókő, az Arvisura esetében többek között Ataisz vagy a Palócföld. Ezeket a helyeket spirituális hatalommal ruházzák fel, amelyek általában a magyarság kiválasztott szerepét hivatottak altámasztani és hangsúlyozni. Mindkét kultusz elsődleges céljának tekinthetö a rejtett tudás felkutatása és a magyarok megérdemelt dicsőségének ezáltal való visszaállítása. Ezt a feltárást hivatott segíteni a különböző tudományágak bevonása; ilyen a régészet, a történet-, a nyelv- és a vallástudomány (pontosabban azoknak a saját értelmezésük szerinti, „nem hivatalos” változatai). A rendelkezésre álló források közül ugyanis szelektálnak; csupán azokat veszik figyelembe, amelyek álláspontjaikat igazolni látszanak. A tudományos kutatási módszereket és eredményeket nem veszik figyelembe, vagy nem rendeltetés szerint alkalmazzák. (Vö. IMREH 2014: 106-110.)

Ezzel eljutunk egy másik kapcsolódási ponthoz: a tudományossal szembeni tartózkodáshoz. Azok az eredmények, amelyek eltérnek a kultusz által elvártaktól, hívőik szemében nem tekinthetőek hitelesnek, mert valamilyen külső erő befolyása alatt születtek azzal a céllal, hogy a magyarok előtt fedve maradjon nemzeti eredetük és hivatásuk. Ezért a kultuszok előszeretettel fordulnak a paratudományos vizsgálódási módszerekhez, spirituális technikákhoz. Ezek előnye a tudományos módszerekkel szemben, hogy nem igényelnek szaktudást, részletes előismereteket, kritikai szemléletet; alapjuk a hit, így bárki által befogadhatóak addig, amíg ez a hit valamilyen biztos alapon nyugszik (pl. a magyarok kitüntetett szerepe a történelemben). Ilyen spirituális eszköz a Pilis-kultuszban a földsugárzások alternatív mérése, ${ }^{1}$ az Arvisurában pedig a gondolat-vibrációs eljárás. ${ }^{2}$ (Vö. IMREH 2014: 107-109.)

\footnotetext{
${ }^{1}$ Ezoterikus eszközökkel történő, tudományosan nem alátámasztott földvizsgálatok.

${ }^{2}$ Paál Zoltán megfogalmazása szerint egyfajta telepatikus kapcsolatteremtés. A fogalmakat, neveket - köztük az eseményekét is - az Arvisurák írásmódjában közlöm.
} 
Szintén a formai és tartalmi kötöttség hiányának tudható be, hogy a kultuszok körében kimagasló szerep jut az internetnek. Ott ugyanis bárki publikálhatja írásait a témában, a laikus olvasó pedig nem rendelkezik akkora tudományos tapasztalattal és forráskritikai érzékkel, hogy szelektálni tudjon a hiteles és a hiteltelen között. Ráadásul a videómegosztó portálok már az olvasást is szükségtelenné teszik e témában. (Vö. IMREH 2015: 119.)

Ahogy már fentebb említettem, a számtalan hasonlóság ellenére az Arvisura-kultusz sok jegyében el is tér a Pilis-kultusztól, illetve az egyéb ideológiáktól. Míg a Pilis-kultuszt több, egymás mellett gyakran elbeszélő szerző tevékenysége alakítja (IMREH 2014: 107-108), addig az Arvisura-kör egyetlen személy, Paál Zoltán alkotása. Persze ez a kijelentés csak akkor állja meg a helyét, ha figyelmen kívül hagyjuk, hogy Paál számos különböző mitológiából és mondavilágból (az uráli nyelvcsaládhoz tartozó nyelveket beszélő népekéből is) kölcsönöz motívumokat, sőt teljes történeteket. Bár a kultuszokra általánosan jellemző a következetlenség és az ellentmondások elfogadottsága, az Arvisura ezt új szintre emeli. A mü egyes fejezetei vagy akár egy fejezeten belüli részei is nemegyszer olyan mértékben mondanak ellent egymásnak, hogy az a teljes alkotás értelmezését teszi szinte teljesen lehetetlenné. Ezért tanácsosabb írások gyüjteményeként tekintenünk a kötetekre, mintsem egységes müként, hiszen az egyes részek között jelentős tartalmi, formai, stílusbeli, nyelvezeti különbözőségek fedezhetők fel, és az Arvisura egységes voltának látszatát az összekapcsoló, rendszerező elv teljes hiánya is fokozza.

Publikációk szempontjából az Arvisura-kör nem olyan kiterjedt, mint a Pilis-kultusz. Bár Paál Zoltán halála után a felesége és a szükebb követői kör tagjai továbbra is igyekeznek kisebb írásokkal támogatni a kultusz fennmaradását, az Arvisura-kör fő színterévé mára a már említett internetes oldalak váltak. Fontos még megemlíteni, hogy több naptár, laikus keresztnévszótár és névkereső szintén előszeretettel merített az Arvisura névállományából, így ezekre is tekinthetünk úgy, mint a kultusz valamiféle „leszármazottjaira”. Ilyen laikus munkákat tárgyalnak például FARKAS $(2006,2019)$ és SLíz (2018, 2020a, 2020b) cikkei.

Talán a legszembetünőbb eltérés mégis az, hogy míg a Pilis-kultuszban a helynevek, addig az Arvisura körében a személynevek és a névadási hagyományok bírnak a legnagyobb jelentőséggel.

3. Paál Zoltán és az Arvisura - Igazszólás. Az Arvisura Paál Zoltán főművének tekinthetö; egyszerre tartja világtörténelmi szinten is jelentőségteljes krónikának, valamint a magyar nyelvről alkotott kép újragondolásának (föként a nevek tekintetében), de a világ kialakulásáról is egyéni elképzeléssel rendelkezik.

Paál Zoltán egy Ózd melletti kis településen született és élt. Előbb az Ózdi Vasgyárban dolgozott, később a Rimamurány-Salgótarjáni Vasmű Rt. kohásza volt. A fordulópontot az életében 1944 hozta, amikor a munkaszolgálatból megszökve megismerkedett Szalaváré Turával, aki a manysi fősámán unokájának mondta magát. Paál elmondása szerint Tura bevezette őt az Arvisurák rendszerébe, és kiválasztottnak kiáltotta ki. A háború után Paál hazatért, csatlakozott az Ózdi Irodalmi Körhöz, és megkezdte írói-kutatói pályafutását. Előbb főként a palóc legendákat, hagyományokat kutatta saját származásának okán; ezek még kéziratos, valamint illegális kiadásokban jelentek meg (Kozsdi 2005). Aztán ezeket a Püski Kiadó több mint ezer oldalon, két kötetre bontva megjelentette Arvisura - Igazszólás: mondák, regék, népi hagyományok a palóc kézmüvesek világából címmel (Paál 1997-1998).

De mik az Arvisurák? A szó jelentése a szerző szerint: 'igazszólás, minden, ami igaz'. E mitológia leginkább Szalavaré Tura történeteinek és Ardvisura Anyahita nagyasszony 
gondolat-vibrációs eljárással közvetített információinak fúziójaként értelmezhető, amelyet Paál Zoltán lejegyzésében ismerhetünk meg. Az Arvisurák egy hitvilág, világnézet egyetlen és fö iratának tekinthető. A középpontban a palóc eredetü, kiválasztott lovasnomád nép áll, akiknek a történetét Ardvisura Anyahita és az őt követő rovósámánok az Özönvíz elötti, Ataisz nevezetü őskontinens korától egészen napjainkig lejegyezték.

Mivel a Paál Zoltán által biztosított írásokon kívül semmilyen más forrás nem áll rendelkezésre, amely alátámasztaná állításait, és az Arvisurák hitelességét bizonyítaná, az iratok tartalma a legnagyobb jóindulattal is megkérdőjelezhetőnek nevezhető.

A legteljesebb kiadás (Paál 1997-1998) felépítése, elrendezése nehezen értelmezhető első pillantásra. Az elő- és utószavakat, valamint a köszönetnyilvánításokat figyelmen kívül hagyva a közel ezerötszáz oldalas mủ tíz nagyobb részre tagolódik. Ezek önálló kezelése szinte lehetetlen: tartalmuk, vonatkozásaik általában egybefolynak, és az egész szöveget előre- és hátrautalások szövik át. Az alábbiakban ismertetem a részek címét és azt, hogy mivel foglalkoznak, de mindegyiket részletesebben elemezni, valamint példával szemléltetni nem áll módomban.

Az I. rész igyekszik bevezetni az olvasót ebbe a bonyolult, gyakran átláthatatlan rendszerbe. Egyrészt itt olvasható Paál Zoltán hagyatéka és kapcsolata röviden az Arvisurákkal, valamint Paál elképzelése, célja írásával kapcsolatban. A szerző továbbá itt közli levelezéseinek is egy részét, amelyek értelmezési segédletként, valamint forrásként is szolgálnak. A palóc (úz) nép ${ }^{3}$ regevilágának vázlatos ismertetője is ebben a részben olvasható.

A II. rész a már fentebb említett sorsfordító találkozás részleteit írja le Paál és Szalavaré Tura között. Részletes névlistával szolgál Tura rokonai köréből, valamint jó pár dátumot is közöl, hogy jobban el tudjuk helyezni kettejük történetét térben és időben. Megtudjuk, Tura hogyan tette látóvá Paált, s az utóbbi hogyan jutott birtokába az Arvisuráknak. KLIMA LÁSZLÓ 2009-2010-ben részletesen foglalkozott a müvel a Rénhírek blogon. Nyolc bejegyzése készült a témában, ezek mindegyike elérhető az Arvisura címszó alatt. KLIMA többek között arra is rámutatott, hogy a II. részben lejegyzett dátumok és helyszínek eléggé ellentmondásosak, és jócskán felborítják az idősíkot. Bizonyos, hogy a találkozás nem úgy zajlott, ahogyan azt Paál részletesen leírja, de az is kérdéses, hogy egyáltalán megtörtént-e, és ha igen, kivel is találkozott valójában a szerző.

A III. rész az ún. sztrecsnói rituális medvetor öt napját írja le, amelynek során az ordoszi törzsszövetség 24 törzse közül kivált manysik átadták az Arvisurák lerovásához szükséges tudást az úzoknak.

A IV. rész az Arvisurák lerovásának művészetébe enged betekintést. Hogyan, kik jegyezték le ezeket, milyen nehézségekbe ütköztek, mely nyelven íródtak, és melyek olvashatóak a mai emberek számára.

$\mathrm{Az}$ V. rész a maga több mint ezer oldalával a kötet legterjedelmesebb egysége. Ez a rész tartalmazza magukat az Arvisurákat, Paál Zoltán értelmezésében és megjegyzéseivel. Bár nem hiánytalanul, de összesen 350, gyakran betüjeles részletekre is tagolt Arvisurát tartalmaznak a kötetek.

\footnotetext{
${ }^{3}$ A szerző a palócokra külön népként tekint. Gyakran az úz és a magyar néppel is azonosítja őket. A szövegekből továbbá az következtethető ki, hogy a szerző szerint e népek nyelve is azonos. Ez az „úz (palóc)” nyelv a szerző szerint szinte teljesen megegyezett a mai magyarral, és a ragozó nyelvek családjába tartozott.
} 
A VI. részben találhatók azok az epizodikus, meseszerü történetek, amelyek kanonikusan nem sorolhatók be az Arvisurák kronológiai sorrendet következő rendszerébe.

A VII. rész tartalmazza a fósámánok, rovósámánok és aranyasszonyok rendjét. Paál állítása szerint az új rovások időszámításától, vagyis amikor a manysik az úzokra hagyományozták az Arvisurák jogát, egészen 1780-ig jól dokumentálva van a rovásokkal kapcsolatos személyek listája. Ennek ellenére ez a rész ugyanúgy dokumentálja az időszámításunk előtti 4000-es éveket, mint az időszámításunk szerinti 20. századot. A lista tartalmazza az adott Arvisurához köthető uralkodók, azaz fösámánok, valamint a rovósámánok és a mitikus aranyasszonyok nevét, mindezt akár évtizedes pontosságú datálással. Ha ezeket a neveket összevetjük az Arvisurákkal foglalkozó V. fejezettel, ismét ellentmondásokba ütközünk. Például a 298(D). jelzettel közreadott Arvisurát Kr. u. 980-1070re datálja és Piroska-Abalán rovásának nevezi a szerző. Ha összevetjük ezt a VII. fejezet rendjével, azt látjuk, hogy 980-1070 között nem jegyez sem ilyen nevezetủ rovósámánt, sem fósámánt, hanem az aktuális aranyasszonynak tulajdonítja a rovást, holott korábban azt írja, ilyenkor ők már nem róttak.

A VIII. rész tartalmazza a FÉRANt, azaz a Beavatottak Névadó Naptárát. Ennek névtani szempontú vizsgálata és elemzése tanulmányom elsődleges célja.

A IX. rész a Levélkivonatok, melynek szerepével kapcsolatban a szerző egyértelmü szándékát közvetve sem közli.

A X., utolsó rész a forrásmunkák jegyzéke. A források kimerülnek a korábban bemutatott Arvisurákban, amiket a szerző Szalaváré Turától kapott másolat formájában. Ezeken kívül több helyen utal általánosságban Szőnyi Márton hadtörténeti jegyzeteire, valamint Körösi Csoma Sándor gyüjtésére. Ezek a jegyzetek, ha valahol léteznek is, nagyon nehezen értelmezhetők hiteles forrásként az Arvisurához. Összefoglalva: nincs olyan forrás, amit Paál Zoltán hitelesen fel tudott volna mutatni írása háttereként.

Paál Zoltán müve inkább egyfajta kreált mitológia, tudományos célokat nem fogalmaz meg; írásai összeszedetlenek, rendszertelenek, az esetek túlnyomó részében következetlenek, ellentmondásosak.

4. A Beavatottak Névadó Naptárának és névadási hagyományainak bemutatása. A FÉRAN naptár története, más néven a 350(B). Arvisura sem könnyíti meg az értelmezést. A szerző állítása szerint 1980-ban lezajlott a Vízöntő Világhónapjának Nagyszalája, ahol többek között az illetékes kiválasztottak elhatározták, hogy innentől minden ember kötelessége a Világbékéért küzdeni. Itt esett először szó arról, hogy a Palóc-FÉRAN létezését kutassák. Ez az ősi irat, amely „feltehetőleg a Melegvizek-birodalmából maradt ránk”, Paál állítása szerint (a teljesség igénye nélkül) járt Mátyás királynál, Farkas Lándor böszörmény vezérnél, Magyar-Agli basánál, Rákóczi Györgynél, illetve Bethlen Gábornál is.

A Palóc-FÉRAN a beavatott társadalmak névadási szokásainak Kr. e. 48 000-től napjainkig tartó hagyományát örökíti meg, illetve annak fejlődését mutatja. Az Élettemplomában elhelyezett eredeti FÉRAN 63000 nevet, minden napra 24-et tartalmazott. (A naptár egy évre 386 [!] napot számol, amely 24-gyel szorozva is csupán 9192 név. Erre nem ad magyarázatot a szerző.) A naptárt Ataisz elsüllyedése után (itt Kr. e. 5038) elöször Kr. e. 3970-ben újították meg. Mivel ekkorra az eredetileg 24 törzsből álló Hun Törzsszövetség tagjainak száma 12-re csökkent, a ránk maradt FÉRAN csupán napi 12-12 férfi- és női nevet tartalmaz. 
Az oszlopokba rendezett névjegyzék bal oldalán találhatók a FÉR, azaz férfinevek, míg a jobb oldalán az AN, azaz az „asszonynevek”. Mindkét oldalon napi 8 ataiszi és 4, Kr. u. 29-ben kialakult, ún. uruki-mani név található. Az uruki-mani nevek azokból a - Paál Zoltán szerint - Jézus által Uruk városába írt levelekből eredeztethetők, amelyek úz-palócul íródtak. Több név akár egy hónapon belül is ismétlődik. Arra is van példa, hogy egy név a FÉR és az AN oszlopban is megjelenik. Az ataiszi nevek is elöfordulnak az uruki-mani nevek között és fordítva. Ez is eleve megkérdőjelezi a szerző kijelentését, miszerint az urukimani nevek eltérő eredetüek, mint az ataisziak. (Az ataiszi és uruki-mani nevek megoszlása a későbbiekben még szerepet kap a névanyag vizsgálatában.)

Néhány név mellett évszámok találhatók. Ezek azt jelölik, hogy az aktuális Nazir, azaz 25 karéjos Istenfia születése elött kik voltak azok a személyek, akik 10 karéjosnál ${ }^{4}$ erősebb beavatottak voltak, és így elörébb vitték az emberiség fejlődését. Minden hónaphoz társul egy FÉRAN-beli elnevezés is. A Tigris-Almaszüret hava a szeptember, a Medvetor hava a január, a Gödölyetor, Eper-hava pedig a június megfelelője. Azonban a hatodik hónaptól kezdődően a FÉRAN-hónapok határai nem egyeznek meg a valós hónapokéval. Így például a Gödölyetor, Eper-hava már május harmincadikával kezdetét veszi. Ráadásul december után található még húsz további nap, amelyek a férfi oldalon a Tárkánynapok, a női oldalon a Holdnélküli napok elnevezést kapják.

A jegyzék értelmezéséhez szükséges még ismernünk az egy-, két-, három- és négylelkü gyermekek fogalmát. Ez a nagyszülökben történő lelki változással kapcsolható össze, amely annak köszönhető, hogy az unoka születése lelki megújulást hoz magával. Így azok a gyermekek, akiknek születésük idejében még mind a négy nagyszülöjük élt, négylelküek lettek, és ehhez mérten a FÉRANból négy szótagú nevet kaptak. Azok a gyermekek, akik több lélekkel bírtak, azaz több nagyszülöi életenergiát kaptak, erősebbek, fejlettebbek lettek társaiknál. Mindezek mellett a nevek az adott napra eső csillagképek alakzatait is megnevezték. Tehát a 24 törzs idején egy emberröl tudni lehetett azt, hogy mely napon született, milyen csillag- és bolygóállások alatt, melyik törzshöz tartozik, és hány lelke van, mindezt csupán a neve alapján. ${ }^{5}$ Ha egy négylelkü gyermek született, de az adott napon csak egy, két, esetleg három szótagú nevek álltak a FÉRAN-ban, akkor „ragozással” könnyen alkothattak a tőből akár négy szótagú alakot is.

Ezt a ragozási eljárást példával is szemlélteti a szerző. A Giz egylelkü névből alkothatunk Gizeh, Gizel, Gizella, illetve Gizellácska neveket is a lelkek számának megfelelöen (Paál 1997-1998. 2: 1325-1326). Látható, hogy a szerző a ragozás terminust általánosan használja a névalkotási módszerekre: ha a szótőre új szótagot illesztünk, akkor az így keletkezett név az eredetinek a ragozott változata. Ezen az alapelven kívül a szerző semmilyen korlátozó szabályt nem fektet le, feltételezhető tehát, hogy minden ragozott alak elfogadható a névadásban. Ebben az esetben viszont megkérdőjelezhetővé válik egyúttal az ősi neveknek tulajdonított spirituális hatalom és a névadási hagyomány fontosságának hangsúlyozása.

5. A FÉRAN neveinek névtani szempontú elemzése. Az elemzésemhez a Medvetor havának (azaz januárnak) a névállományát választottam. Ez az adathalmaz jól szemlélteti a szerzőre jellemző névalkotási típusokat és azok számbeli megoszlását. Minden napra

\footnotetext{
${ }^{4}$ A karéj a szellemi erő megnevezése és mértékegysége is egyben.

${ }^{5}$ Ez a névnaptár mindenki számára értelmezhető volt a szerző szerint, ugyanis kezdetben mind a 24 törzs az úz (palóc) nyelvet beszélte.
} 
12-12 férfi- és női név jut, ez január harmincegy napjával számolva összesen 744 nevet jelent. Az elemzés elött fontos még megjegyezni azt, hogy - mint már fentebb is utaltam rá - néhány név megjelenik az ataiszi és az uruki-mani nevek között is (pl. a végsö névalkotó mozzanatát tekintve magyar eredetü Vince $e^{6}$ férfinév). Valamint elöfordul olyan név is, amely ugyanazon a csoporton belül ismétlödik ( $\mathrm{pl}$. a germán eredetü Lóránt férfinév). Ezt megjegyezve a továbbiakban is minden egyes nevet külön adatként kezelek, ahogyan ezt a szerző is tette.

5.1. A FÉRAN-ban előforduló, ma anyakönyvezhető nevek eredete. A vizsgálat első szempontjaként arra voltam kíváncsi, hogy egyrészt a FÉRAN-ban mekkora arányban szerepelnek ma adható keresztnevek, másrészt hogy hatással lehettek-e a FÉRAN feltehetőleg a szerző által alkotott nevei a magyar keresztnévadásra, s ha igen, milyen intenzitással. Megnéztem ezért, hogy az itt szereplö nevek ma anyakönyvezhetők-e Magyarországon. Ehhez a Nyelvtudományi Intézet által anyakönyvi bejegyzésre alkalmasnak minősített utónevek jegyzékének 2020. márciusi állapotát vettem alapul. ${ }^{7}$ A 744 névből ma csupán 177 (23,8\%) anyakönyvezhető, pedig a FERAN elkészülte, azaz 1972 óta is számos új név vált bejegyezhetővé. A nemek megoszlása szerint 117 férfinév és 60 női név adható; ez a FÉRAN férfineveinek 31,5\%-a, a női neveinek pedig mindössze 16,1\%-a. Az anyakönyvezhető férfinevek közül 38 (32,5\%) ataiszi és 79 (67,5\%) uruki-mani. A női nevek közül $18(30 \%)$ az ataiszi és 42 (70\%) az uruki-mani csoportba tartozik, ebben tehát nincs különösebb eltérés a nemek között. Ez a megoszlás azért is érdekes, mert a vizsgált hónap teljes névállománya kétszer annyi ataiszi nevet tartalmaz, mint uruki-manit. Ennek az egyik lehetséges magyarázata az lehet, hogy a szerző szerint az uruki-mani nevek újabbak, így közelebb állhatnak a mai magyar nevekhez. Elképzelhető, hogy a szerző ennek alátámasztása érdekében a biztosan anyakönyvezhető neveket inkább az uruki-mani csoportba osztotta.

$\mathrm{Az}$ anyakönyvezhető neveket eredetük szerint is megvizsgáltam, hogy kiderüljön, hányféle forrásból származnak a FÉRAN nevei, melyeket a szerző ősmagyarnak tekintett. Az eredet szerinti kategorizációt a MUnk. 1998-as kiadására épülő Utónévkereső ${ }^{8}$ segítségével végeztem el. Az eredet-en azonban a továbbiakban a közvetlen átadó nyelvet értem, ${ }^{9}$ mivel ez tükrözi híven az átvétel korabeli nyelvi kapcsolatokat (vö. SLíz 2020b: 496). Az Utónévkereső viszont - mint általában az utónévkönyvek (p. MUnk., KnE., FerCsiKRAÁTz 2017) - többnyire nem ezt az elvet követi, így néhány esetben változtatásokat eszközöltem annak kategorizálásához képest az alábbiak szerint:

1. A nyelvújítási eredetűként megjelölt neveket egységesen magyar eredetűnek tekintettem. Hasonlóan jártam el a magyar szerzőknek (pl. Arany Jánosnak, Anonymusnak) tulajdonított nevek esetében.

2. A germán és a német eredetü nevek elhatárolása nem volt egyértelmü, ezért ezeket a germán/német eredetü típusba vontam össze.

\footnotetext{
${ }^{6}$ A nevek eredet szerinti besorolását 1 . az alábbiakban.

${ }^{7}$ Férfinevek: http://www.nytud.mta.hu/oszt/nyelvmuvelo/utonevek/osszesffi.txt, női nevek: http:// www.nytud.mta.hu/oszt/nyelvmuvelo/utonevek/osszesnoi.txt

${ }^{8} \mathrm{http}: / /$ corpus.nytud.hu/utonevportal

${ }^{9}$ Ennek okát, illetve a terminus egyéb lehetséges értelmezéseit részletesen 1. SLíz (2020c).
} 
3. A görög vagy latin eredetűek a legtöbb esetben szintén nem különíthetőek el világosan egymástól, így ezeket a görög-latin eredetü típusba vontam össze. Ide soroltam a héber, akkád, perzsa, arámi stb. eredetünek megjelölt bibliai neveket is, hiszen ezek is egyházi görög vagy latin közvetítéssel kerültek a magyarba.

4. A török és ótörök eredetűként jelölt nevek elhatárolása sem volt mindig egyértelmü, ezért ezeket az (ó)török eredetü típusba vontam össze.

5. A névszótárakban régi magyarként megjelölt nevek között találhatóak (ó)török eredetüek is, így ezeket átsoroltam az (ó)török eredetü típusba. Az átsoroláshoz útmutatóul HAJDÚ (2003: 356-358) ómagyar kori török eredetü nevekröl szóló bekezdéseit, illetve Stíz MARIANN Anjou-kori személynévtárának $(2011,2017)$ etimológiai megjegyzéseit használtam.

6. Ha a magyarban történt a névvel morfológiai változás, akkor azt magyar eredetünek jelöltem, hiszen az utolsó névalkotó mozzanat a besorolás alapja (vö. HAINDRICH 2019: 147, SLíz 2020c: 71-72). Ilyen például az Apolka, amely a latin Apollóniá-ból lett a magyarban elvonással Apol-, majd -ka képzöt kapott.

Ezek alapján az anyakönyvezhető csoporton belül kilenc típust állapítottam meg (vö. 1. ábra). A 177 anyakönyvezhető név közül 60 (33,9\%) magyar (pl. Gyözö, Vidor; Aranka, Virág), 57 (32,2\%) görög-latin (pl. Makár, Julián; Maja, Laura), 21 (11,9\%) germán/német (pl. Ede, Lotár; Zita, Zelma), 14 (7,9\%) bizonytalan eredetü (pl. Csörsz, Botár; Kéra, Genovéva), 14 (7,9\%) (ó)török (pl. Jutas, Dormán; Sarolta), 6 (3,4\%) szláv (pl. Vászoly, Ulászló; Milla, Vanda), $2(1,1 \%)$ hun, ${ }^{10} 2$ (1,1\%) francia (Adél és Lujza) és $1(0,6 \%)$ sumér ${ }^{11}$ eredetü.

1. ábra: Az anyakönyvezhető nevek megoszlása nemek és eredet szerint

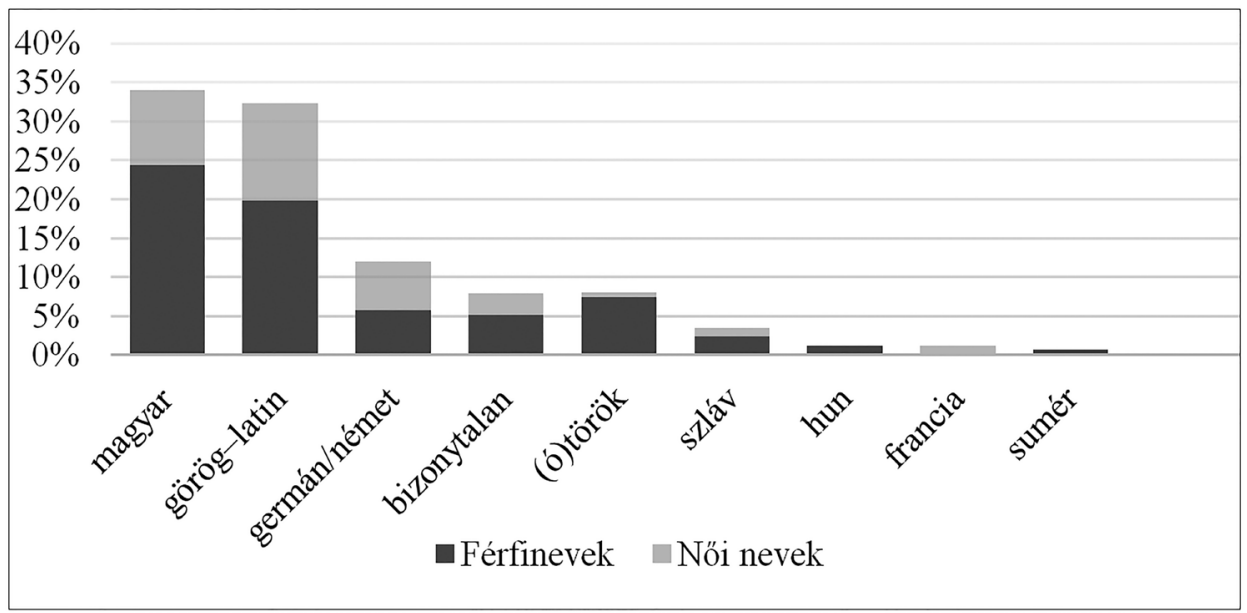

${ }^{10}$ Vagy legalábbis a hun mondakörbe tartozó: a Balambér férfinév két előfordulása.

${ }^{11}$ A Gilgames név, mely müfordítás révén került a magyarba. 
2. ábra: Az anyakönyvezhető férfinevek megoszlása eredet szerint

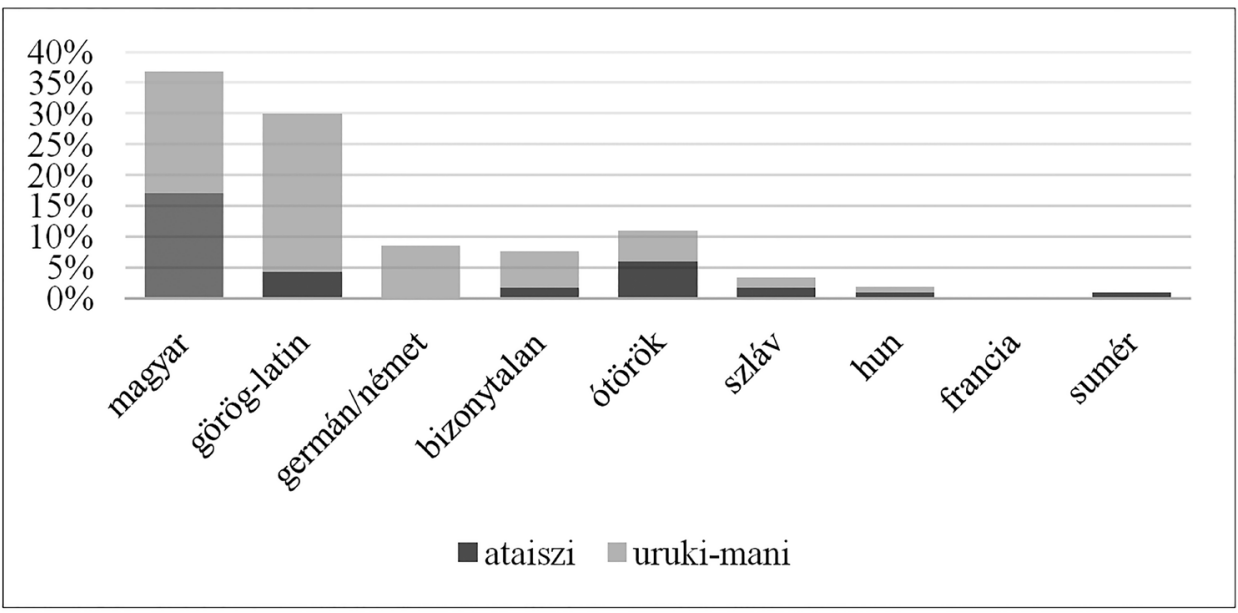

3. ábra: Az anyakönyvezhető női nevek megoszlása eredet szerint

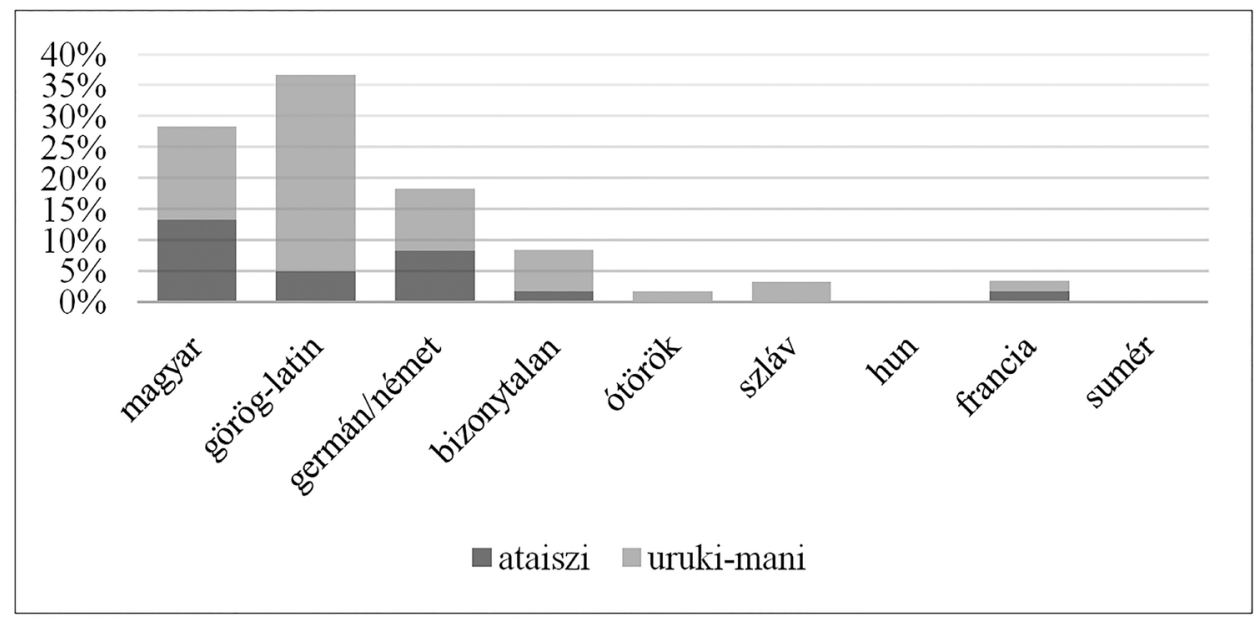

A 2-3. ábrán látható, hogy míg a férfinevek esetében a magyar eredetủ a leggyakoribb típus, addig a női nevek között a görög-latin eredetű nevek fordulnak elő a legtöbbször. A 177 anyakönyvezhető névnek a magyar eredetüek alig egyharmadát teszik ki. Ez az arány nem nevezhető nagynak, ha figyelembe vesszük, hogy a szerző leírása alapján a nevek mindegyike az ősi magyar nyelvböl származik. Ez az arány ennél is tovább csökken, ha nem csak az anyakönyvezhető neveket számoljuk. A vizsgált 744 névnek csupán a 8,1\%-a bizonyítottan magyar eredetü, anyakönyvezhető utónév. 
Az eredet kapcsán fontos még megjegyezni, hogy két alkalommal, a Fábián (göröglatin eredetü, ataiszinak tekintett név) és a Virgilia (nem anyakönyvezhetö, uruki-maninak tekintett név) mellé a szerző beilleszti az etr. betüsort. Elképzelhető, hogy ez az etruszk rövidítése, és a név eredetére hivatott utalást tenni, bár a szerző nem közli a rövidítések magyarázatát. Hasonló az Artur (nem anyakönyvezhető, uruki-maniként közölt név) esete is. Itt a szerző az (öregúr) megjegyzést helyezte el a név mellett; feltételezhetőleg e szóból vezeti le a nevet.

\subsection{A FÉRAN-ban előforduló, nem anyakönyvezhető nevek jellemző típusai}

5.2.1. Átvett nevek. A szerző által különböző forrásokból átvett nevek közé tíz férfinév sorolható. Ilyen az uruki-maniként kategorizált Ahti férfinév: Ahti ugyanis a finn mitológia és népköltészet egyik hösi karaktere. A szintén uruki-maninak állított Cirus férfinév valójában Kürosz perzsa nagykirály nevének a latin alakváltozata, az ataisziként közölt Mundzuk pedig a monda szerint Attila hun király apjának volt a neve.

5.2.2. Morfológiai névalkotással létrehozott nevek. Az író által alkotott nevek egyik jellemző típusát az összetétellel létrehozottak alkotják. A Kondábel férfinevet például a szerző a Kond személynévből és az Ábel görög-latin eredetü keresztnévböl alkothatta meg. Az Abavér női név esetében az Aba (ó)török eredetü férfinevet láthatta el a -vér utótaggal. A -lány utótaggal alkotott női nevekre ebben a hónapban két példa található, de a névtárban bőségesen előfordulnak, tehát tipikusnak tekinthetőek. Az egyik az Adrilány, amelyet valószínüleg az Adrienn francia eredetü keresztnév becenevéböl alkothatott meg a szerzö, a másik pedig a Kustilány, amelynek az előtagja feltehetőleg szintén a szerző alkotása.

Szintén gyakori csoportot alkotnak a képzéssel létrehozott nevek. Ezek egy részének a töve egy-egy, azonos nemhez kötődő anyakönyvezhető keresztnév. Ide tartoznak például az -s képzővel (pl. Bálintos) és a - $d$ képzővel (pl. Aladárd, Gyöngyvérd) keletkezett nevek. A férfinevek női párjai a mai magyar keresztnévállományra is jellemzőek; ezt a típust itt egyedül a Balázsa képviseli. A személynevek mellett helynevek is szolgálhattak a képzés alapjául; e típusba kizárólag női nevek tartoznak (pl. Zilah > Zilahos). Köznevekből is hozott létre a szerző neveket: ilyenek például az -i képzővel létrehozott Sajti és Lángi női nevek vagy a szilva köznévből képzett Szilvád férfinév. A képzők közül különösen kedvelhette a szerző a -ka/-ke kicsinyítő-becéző képzőt. Ezzel ritkán férfineveket is képzett (a januári nevek közül a Polemká-t és a Garbonká-t), a képzett női nevek legtöbbje viszont ide sorolható, akár további képzőkkel is bokrosítva (pl. Bironka, Arzike, Odilódka). Ez persze nem meglepő, hiszen e képző az anyakönyvezhető nőinév-állományra is jellemző, illetve bővülésének tipikus módja a becézőnevek keresztnévvé tétele, így a valós névanyag e névalkotások modelljeként szolgálhatott.

A jóval ritkább, elvonással létrehozott nevek közé tartozhat például a Szoraj, amely a perzsa eredetü Szoraja női név férfi párja lehet. A szerző e módszert inkább a többi típusba tartozó módszerekkel kombinálva alkalmazza.

5.2.3. Jelentésbeli névalkotással létrehozott nevek. A morfológiai névalkotással létrejött nevek mellett az egyik leggyakrabban előforduló típus a FÉRAN-ban a jelentésbeli névalkotással létrehozott neveké. Ide tartozik minden olyan név, amely morfológiai eszközök nélkül, kategóriaváltással vált keresztnévvé (vö. HofFMANN 1993: 93). 
A típuson belül a közszóból keletkezettek alkategóriáját névszói és igenévi, valamint igei eredetủ altípusokra osztottam tovább. A névszóból keletkezettek közé tartoznak például a Sas, Bödön és Bor férfi-, valamint a Dunna, Gerlice és Tuba női nevek. A fönevek mellett a mellékneveket, illetve a melléknévi igeneveket is gyakran használja fel a szerző keresztnévként (pl. Haragos és Borosztó férfinevek, Pirinyó női név). Az igéből keletkezettek alkategóriájába a férfinevek közül a Csal és Szörcsög tartozik, női névre viszont a vizsgált névállományban nincs példa (Megjegyzendő, hogy e nevek némelyike akár irodalmi névként, akár ómagyar kori személynév felélesztéseként is felfogható; pl. Bor, Haragos; vö. SLíz 2017. Bur a., HaJdú 2003: 354.)

A kategóriaváltással férfinévből nőivé, illetve a női névből férfivé vált nevek altípusába azok tartoznak, amelyek az egyik nem esetében anyakönyvezhetőek, de a szerző az ellenkező nem oszlopában helyezte el őket. Ilyenek a Berta és Gerda germán/német és a Jácinta göröglatin eredetű női nevek, amelyek itt férfinevekként vannak feltüntetve. A Marcel, Marcell, Vitus, Gede, Bod és Surány anyakönyvezhetö férfinevek (habár a Surány helynévként ismertebb lehet), itt viszont nőiként szerepelnek. Az altípusba tartozó görög-latin és germán/ német eredetü nevek uruki-maniként, míg a magyar és (ó)török eredetüek ataisziként vannak feltüntetve. Ismét feltételezhető, hogy a szerző így próbálta a magyar és (ó)török neveket a régebbinek tekintett rétegbe helyezni. A Bod és Surány egyébként szerepel a férfinevek között is, szintén uruki-maniként jelölve.

A becenevekből kategóriaváltással létrehozottak közé tartoznak például a Katika, Nóriska, Melánka, Adélka, Zsuzsácska, Veruska női nevek. Ebben az altípusban - az anyakönyvezhető névállomány bővülése kapcsán fentebb mondottaknak megfelelően, nem meglepő módon - csak női névre találunk példát a névállományból. A családnévből kategóriaváltással keletkezett nevek közé tartoznak többek között a Rátkai, Barócz férfinevek. A női nevekre példa az ataisziként megjelenített Kollár, Vámos és Agód.

A helynevekből keletkezett alkategória nevei beoszthatóak három nagyobb csoportba. Az első a mai Magyarország területén található helyek neveit foglalja magába. Ilyen például a Lepsény férfinév, amely egy Fejér megyei nagyközség neve, vagy a szintén férfinévként szereplő Körmend, egy Vas megyei város neve. A női névként feltüntetett $\mathrm{Dubi}$ csány egy Borsod-Abaúj-Zemplén megyében található község nevéből jött létre, a szintén női névként besorolt Kemecse pedig egy Szabolcs-Szatmár-Bereg megyei város nevéböl. A második nagy csoport a mai országhatárokon túli, történelmi Magyarország területén fekvő helyek neveiből keletkezetteké. Ilyen például a Gyimes férfinév, amely a mai Románia területéről származó helynév, vagy a szintén férfinévként feltüntetett Lippa, amely hasonlóképpen egy, a mai Romániában található város nevéből lett. A női névként besorolt Dobóca és Körtvélyes is egy-egy, a mai Szlovákia területén található község neve. A harmadik nagy csoport a helynevekből alkotott keresztnevek alkategóriájában az idegen országok helyneveiböl keletkezetteké. A Mezeny férfinév például egy oroszországi településnek és folyónak is a neve, a Tanger férfinév pedig egy marokkói kikötővárosé, habár ezek természetesen csak a nevek valószínüsíthető előzményei. Ilyeneket csak a férfinevek között találunk, és mind az ataisziak között szerepelnek. Mivel a szerző szerint, mint láttuk, az uruki-mani nevek az idegen nevek közvetlen elődjeinek tekinthetőek, meglepő lehet, hogy a valóban idegen helynevek mindegyike az ataiszi csoportban szerepel.

A régi nevek felélesztése is kedvelt módszere lehetett a szerzőnek. Ilyen például a Kusid ómagyar kori egyénnév vagy a Szavárd ómagyar kori nemzetség-, néprész- és egyénnév is. 
5.2.4. Helyesírási változatok alkotása. A szerző gyakran élt azzal a lehetőséggel is, hogy létező személy- és helyneveket a napjainkban bevettől eltérö, jellemzően régies helyesírással tegyen ataiszi vagy uruki-mani névvé. Például a mai Ukrajna területén található település, a kárpátaljai Bátyú nevére vezethető vissza a Bátyu férfinév. Hasonlóképpen a magánhangzó időtartamának régies írásmódra jellemző nem jelölése figyelhető meg a Hattyus, Bendeguz és Artur (öregúr) nevekben. A mássalhangzó időtartamának változtatását figyelhetjük meg a Kurittyán-ban (vö. Borsod-Abaúj-Zemplén megyei Kurityán községnév) és a Köttöny-ben (vö. anyakönyvezhető Kötöny férfinév). A Czobanka női név a Pest megyei Csobánka településnév régies írásváltozata, a Salán férfinév pedig bizonyára Anonymus Gesta Hungarorumának Salanus nevére vezethető vissza. A maitól eltérő írásváltozatú nevek esetén persze nem lehetünk biztosak abban, hogy a szerző szándékosan változtatta-e meg az írásmódot, vagy a nevek más, népszerü alakjait ismerte.

Érdemes még említést tenni az indokolatlanul csupa nagybetűvel kiemelt nevek csoportjáról. A férfinevek közül ide tartoznak az ataisziként közölt $J A ́ K, O N D, E D$ és $A S K E L$ nevek, a $L O$ Ó férfinévben pedig még egy szóköz is található. A női nevek közül ide tartoznak az $A S, D E L, B E Z, B E B, M A R I$ és $E T A$, valamint a szóközzel elválasztott $A N$ és $A R$. A szerző nem tesz említést arról, hogy ez az írásmód szolgál-e valamilyen célt, jelent-e valamit a FÉRAN rendszerében.

5.2.5. Bizonytalan és ismeretlen keletkezésmódú nevek. Olyan neveket is találhatunk a januárra beosztottak között, amelyeknek több lehetséges eredete is elképzelhető. Az ataiszinak mondott Ordas férfinév például létrejöhetett az ordas melléknévből kategóriaváltással, de akár a Bács-Kiskun megyében található Ordas község nevéből is. A szintén ataisziként feltünő Tajti férfinév létrejöhetett egy, a mai Szlovákia területén található község nevéböl, de a Tajti családnévből is. Hasonló az uruki-maniként közölt Telekes férfinév esete: létrejöhetett családnévből kategóriaváltással, de a Vas megyei Telekes község nevéből is. A hasonlóképpen uruki-maniként kategorizált Szögyén férfinév is kialakulhatott egyrészt egy, a mai Szlovákiai területén található község nevéből, másrészt családnévből is. A Mádé férfinév ómagyar kori egyénnévből és az ebből keletkezett, ma élő családnévből és a Mádéfalva helynév előtagjából is létrejöhetett, így akár felélesztésnek is tekinthetjük. A Turku ataiszi név esete összetettebb. Egyrészt egybeesik a Tihanyi alapítólevél egyik szórványával, így a Törek vagy Töreki helynév egyik ómagyar kori alakjával, de a török közszó ómagyar kori alakjával is összefüggésbe hozható (vö. HoFFMANN 2010: 68-73), sőt egy finn város nevével is. A Kecső férfinév lehet egy ómagyar kori egyénnév felélesztése, emellett azonban a mai Szlovákia területén egy község is található azonos névvel, illetve családnévként is létezik. A Bart származhat az ómagyar kori egyénnévből, amely a Bartholomeus rövidülése, de az azonos családnévböl is. A Teke is lehet egy ómagyar kori egyénnév felélesztése, de létrejöhetett a teke közszóból is.

Hasonló eseteket találunk a női nevek között is. A Tabika tartozhat a -ka/-ke képzős alkategóriába, de besorolhatnánk a helynévi jelentésváltás altípusába is, ugyanis a mai Románia területén található község, Kibéd egyik patakjának is ez a neve. A Csillagos női név létrejöhetett a Csillag magyar eredetü női keresztnévből, de akár a csillagos melléknévből is. Az Örvöske lehet közszóból képzett név, vagy kategóriaváltással is keletkezhetett egy madár nevéböl. Az ardó középkori foglalkozásnév, melynek jelentése 'erdőóvó' (vö. HECKENAST 1970: 91). Az Ardóka megszülethetett úgy, hogy a foglalkozásnevet a szerző egy 
-ka képzővel látta el, de elképzelhetö, hogy inkább a foglalkozásnévből eredő helynevet vagy családnevet vette alapul.

A bizonytalan keletkezésmódú férfinevekre jellemző, hogy egyik lehetséges alkotásmódjuk a régi nevek felélesztése. Ennek az egyik oka lehet, hogy az ómagyar kori egyénés nemzetségnevek nagy gyakorisággal örződtek meg a mai család- és helyneveinkben. Ezzel szemben a bizonytalan kategóriájú női nevek esetében jellemzően a képzés az egyik feltételezhető alkotásmód. Ez nem meglepő, hiszen a női nevek esetében a szerző legkedveltebb módszere a - ka/-ke kicsinyítő képző alkalmazása volt. Ezt az eljárást már a nyelvújítók is szívesen alkalmazták új női nevek alkotására, és ma is használatos a névanyag bővítésére, mint láttuk, így modellként szolgálhatott a szerző névalkotásaihoz.

A FÉRAN-ban az említettek mellett ismeretlen alkotásmódú neveket is bőséggel találhatunk. Némelyikükben felismerhetőek bizonyos közszói és tulajdonnévi elemek, például az ataisziként közölt Abakota férfinévben és Abalén női névben - feltételezhetöen - egyaránt megtalálható az Aba török eredetü férfinév mint elötag. Az Apakán és a Boszkán férfinevekben talán a kán méltóságnév jelenhet meg utótagként, illetve az Apakán esetében az apa közszó előtagként. Míg az előzőek illeszkednek a magyar szavak fonológiai szerkezetéhez, addig a Kapao férfinév szóvégi rövid [o]-ja a magyar nyelvtöl teljesen idegen. Az Alacsány férfinév és a Zala megyei Zalacsány falu neve között is feltételezhető az összefüggés, ahogyan a Sziktivár férfinév is a Komi Köztársaság fővárosának a nevéből (Sziktivkar) jöhetett létre. A Sip, Mosapad és Zsirpud férfinevekben mind felfedezhetö valamilyen közszói eredetü alap.

A női nevek esetében a Garsány lehet a harsány melléknév, a Borsod-Abaúj-Zemplén megyei Harsány, valamint a Nógrád megyei Varsány község nevének eltorzított alakja. A női nevek között is találhatóak olyanok, amelyekben felfedezhetőek a közszói eredet jelei; pl. Rözsel, Csinosdel, Aranyám, Sziabicsaj és Almaje.

Egyes nevek alkotásmódját, illetve eredetét még feltételezés szintjén sem lehet megállapítani. A férfinevek között ilyen a Zsilazhuz, Zsimpali, Unukardé és Toprakál; a női nevek közül az Armuvali, Besemudi, Muzsaketi, Gelendelég és Bajandéleg.

6. Összegzés. A legtöbb hasonló, laikus alkotáshoz hasonlóan tudományos viszonylatban Paál Zoltán múve sem állja meg a helyét, de az esetek többségében a saját logikáját sem követi. A könyv általános bemutatása kellően szemléltette, hogy a felépítése rendszertelen, a történetek egymást cáfolják, bizonyos részek szándéka egyáltalán nincs ismertetve. Ha nem tudományos igényủ munkaként, hanem egy fiktív, alternatív mitológia jegyzékeként tekintünk az Arvisurára, akkor sem mondhatjuk azt, hogy ezek a történetek jól sikerültek lennének. A szerző kritikai érzék nélkül ötvöz mindent a görög mitológiától a finn mondákon keresztül a keresztény hagyományokig. A kiadó, Püski Sándor az Arvisurát - igencsak erős túlzással - Vörösmarty Mihály és Arany János müveihez hasonlítja (Paál 1997-1998: 1442), tehát feltehetőleg irodalmi, nem pedig tudományos alkotásnak tekinti. A névtani elemzés hasonló képet mutat: a FÉRAN nevei sok és változatos forrásból származhatnak, és nehezen rendszerezhetőek. Gyakori, hogy egy név eredetének felfejtése bizonytalan vagy akár lehetetlen. A szerző nem titkolt álláspontja volt, hogy a maival szemben a magyar újszülötteknek az „ősi”, FÉRANban fellelhető névállományból kellene választani. Ahogyan azonban már az elemzés kezdetén láthattuk, a vizsgált névállomány nagyobb része nem ismert, megszokott név, illetve nem része a mai magyar keresztnévanyagnak (nem anyakönyvezhető ma Magyarországon). 
SLíz MARIANN laikus keresztnévszótárakkal foglalkozó írásában (2020a) három típust különböztet meg a szótárak között. Az egyik a parakomparatív, vagyis a magyar nyelvrokonságról a tudományostól eltérö nézeteket hirdetők típusa. E szótárak esetében SLíz a FÉRANt jelöli meg az egyik lehetséges forrásként. A FÉRAN nemcsak terjedelmes névállományával, hanem az Arvisurában tükröződő nyelvi ideológiákkal is mintaadóul szolgált a parakomparatív névtárak számára. Hasonlóan a FÉRANhoz, ezek a szótárak is vegyítik a legváltozatosabb forrású és eredetủ neveket és közszavakat, majd ezeket egységesen (ős) magyar nevekként tüntetik fel. Ezt indokolhatja az a jellemző meggyőződés, hogy a nyelvi sokféleség felemészti a nyelv tisztaságát, és ez végül a nyelv teljes eltünéséhez vezethet. Így a Paálhoz hasonló szerzők feladata, hogy bemutassák a magyar nyelv valódi történetét és rendszerét. A parakomparatív ideológiák egyébként is fontos eszközként alkalmazzák a neveket (1. IMREH 2014, 2015, 2017). Mivel pedig az érdeklődő laikusoknak nincs elég névtani, nyelv- és történettudományi ismeretük és forráskritikai igényük, illetve készségük ahhoz, hogy a hitelest a hiteltelentől megkülönböztessék, egy olyan, több parakomparatív ideológia által is hivatkozott mü, mint a FÉRAN, sokak számára hitelesnek tünő forrássá válhat.

A szakirodalmi áttekintésből is látható, hogy az Arvisuráéhoz hasonló szubkultúra kialakulása nem egyedi eset. Ezek az ideológiai csoportosulások gyakran érintkeznek, keverednek egymással. Előfordulhat, hogy egyes általánosabb elemek, amelyek több ideológiai közegbe is beilleszthetőek, eltávolodnak eredeti környezetüktől, és önálló alkotásként kezdenek el megjelenni. Ez történhetett a FÉRAN névadó naptár esetében is, amely önállósult tartalomként könnyebben feldolgozhatóvá és beolvaszthatóvá vált, mint a nagy és nehezen követhetö Arvisura anyagában.

\section{Hivatkozott források}

Kozsdi Tamás 2005. A magyar ősemlékezet és az Arvisura világkép. Gondolatház, Budapest. MKT. = Magyar Keresztnevek Tára . https://magyarnevek.hu/

Paál Zoltán 1997-1998. Arvisura-igazszólás: mondák, regék, népi hagyományok a palóc kézmüvesek világából 1-2. Püski Kiadó, Budapest.

\section{Hivatkozott irodalom}

FARKAS TAMÁs 2006. Keresztnévkönyvek - keresztnévtárak - keresztnévszótárak Magyarországon. In: Mártonfi Attila - Papp Kornélia - Slíz Mariann szerk., 101 irás Pusztai Ferenc tiszteletére. Argumentum Kiadó, Budapest. 246-252.

FARKAS TAMÁs 2019. Keresztnévszótárak és utónévportálok. In: Vörös FerEnc szerk., A nyelvföldrajztól a névföldrajzig X. Nevek a nyelvpolitikai küzdötérben. Savaria University Press, Szombathely. 63-80.

Fercsik ErzséBet - RaÁtz Judit 2017. Örök névnaptár. A mai magyar keresztnevek legteljesebb gyüjteménye. Müszaki Könyvkiadó, Budapest.

Haindrich Helga AnNa 2019. Keresztnévtörténeti és szocioonomasztikai vizsgálatok Nagykároly környéki sváb eredetü településeken. Doktori (PhD) értekezés. ELTE BTK, Budapest. https://doi. org/10.15476/ELTE.2019.058

Hajdú Mihály 2003. Általános és magyar névtan. Személynevek. Osiris Kiadó, Budapest. 
HeCKENAST GuszTÁv 1970. Fejedelmi (királyi) szolgálónépek a korai Árpád-korban. Értekezések a történeti tudományok köréből. Új sorozat 53. Akadémiai Kiadó, Budapest.

Hoffmann István 1993. Helynevek nyelvi elemzése. A Debreceni Kossuth Lajos Tudományegyetem Magyar Nyelvtudományi Intézetének Kiadványai 61. Debreceni Egyetem Magyar Nyelvtudományi Intézet, Debrecen.

Hoffmann István 2010. A Tihanyi alapitólevél mint helynévtörténeti forrás. A Magyar Névarchívum Kiadványai 16. Debreceni Egyetemi Kiadó, Debrecen.

IMREH RÉKA 2014. A helynevek szerepe az alternatív ideologikus gondolkodásban I. Névtani Értesitö 36: $105-120$.

IMREH RÉKA 2015. A helynevek szerepe az alternatív ideologikus gondolkodásban II. Névtani Értesitő 37: 119-136.

IMREH RÉKA 2017. A laikus nyelvrokonítási kísérletekkel kapcsolatos oktatásmódszertani kérdések. Anyanyelv-pedagógia 10/3: 22-33. https://doi.org/10.21030/anyp.2017.3.2

KLIMA LÁszló 2009-2010. Arvisuráról/1-2, Arvisura/3-8. Rénhírek. http://renhirek.blogspot.com/ search/label/Arvisura (2020. 09. 09.)

KnE. = FercsiK ERzSÉBet - RaÁtz Judit, Keresztnevek enciklopédiája. A leggyakoribb nöi és férfinevek. A Magyar Nyelv Kézikönyvei 16. Tinta Könyvkiadó, Budapest, 2009.

KREKÓ PÉTER 2018. Nagynak lenni múltunk által - mások ellenében. A turanista összeesküvés-elméleti eredetmítoszok szociálpszichológiai háttere. In: BAKRó-NAGY MARIANNE szerk., Ok és okozat. A magyar nyelv eredetéröl történeti, szociálpszichológiai és filozófiai megközelitésben. A humán tudományok alapkérdései 10. Gondolat Kiadó, Budapest. 139-159.

LANSTYÁK IstvÁn 2011. A nyelvi ideológiák néhány általános kérdéséröl. Nova Posoniensia. A pozsonyi magyar tanszék évkönyve 2011: 13-57.

MUnk. = LAdó JÁNOS - BíRó ÁGNes, Magyar utónévkönyv. Vince Kiadó, Budapest, 1998.

SÁNDOR KLÁRA 2011. Nyelvrokonság és hunhagyomány: rénszarvas vagy csodaszarvas? Nyelvtörténet és müvelödéstörténet. Typotex, Budapest.

SLíz Mariann 2011. Anjou-kor személynévtár 1301-1342. Históriaantik Könyvesház Kiadó, Budapest.

Suiz Mariann 2017. Anjou-kor személynévtár 1343-1359. Magyar Nyelvtudományi Társaság, Budapest. https://doi.org/10.26546/5061158

Slíz Mariann 2018. The legal deficiency of publishing calendars and the problems caused by calendars and dictionaries of given names based on lay ideas in Hungary. Onomastica Uralica 10: 309-315.

Slíz Mariann 2020a. A laikus keresztnévszótárak. In: Farkas Tamás - Slíz Mariann szerk., Tulajdonnevek és szótárak. ELTE BTK Magyar Nyelvtudományi és Finnugor Intézet - Magyar Nyelvtudományi Társaság, Budapest. 165-184. https://doi.org/10.26546/4892373.10

Slíz Mariann 2020b. Hungarian non-professional dictionaries of first names. Methodological problems caused by the lack of lexicographic and onomastic knowledge. International Journal of Lexicography 33/4: 488-503. https://doi.org/10.1093/ijl/ecaa009

Slíz MARIANN 2020c. Various interpretations of the term origin in the description of given name systems. Studia Linguistica Hungarica 32: 66-75. http://doi.org/10.5281/zenodo.3907338

ZELLIGER ERZsÉBET 2017. Földrajzi neveink eredetéről - másképpen. Gondolatok néhány közelmúltban megjelent kötet kapcsán. Névtani Értesitő 39: 183-190.

SZABADOS KorNÉL

ORCID: https://orcid.org/0000-0001-6243-737X

ELTE Eötvös Loránd Tudományegyetem Bölcsészettudományi Kar 


\section{Kornél Szabados, Arvisura and FÉRAN, the Name Giving Calendar of the Initiated - Approached through applied onomastics}

The study offers an analysis of Arvisura by Zoltán Paál, and its eighth chapter, the FÉRAN calendar in particular. The primary goal of the research is to identify how the name calendar has managed to stretch beyond its boundaries and remain relevant as a source regarding names to the general public to the present day. Relying on academic literature, the study examines the similarities and differences between Arvisura and other works on alternative theories of language genealogy. The overall structure of the work and its larger sections are presented. The function, sources and method of FÉRAN are examined in detail, as these provide the fundamentals of a detailed analysis. The study is based on the January name stock, a total of 744 names. Onomastic method makes the author's consistent name creating process identifiable. The paper also highlights that the FÉRAN often strays from its own logic, and several names are difficult to categorise or identify. 